\title{
İkinci Eı Kitap Ticareti için Elektronik Pazar Modeli, Yapıcı Sezgisel Yöntemler ve Karınca Kolonisi Optimizasyonu
}

\author{
An Electronic Market Model, Constructive Heuristics and Ant Colony Optimization for Used- \\ Book Trading
}

\author{
Ali Haydar ÖZER ${ }^{1}$ \\ ${ }^{1}$ Marmara Üniversitesi, Mühendislik Fakültesi, Bilgisayar Mühendisliği Bölümü, 34722, Kadlköy, İstanbul, \\ Türkiye
}

\begin{abstract}
$\ddot{\mathrm{Oz}}$
$\mathrm{Bu}$ çalışmada, yeni veya ikinci el kitap ticaretinin yapıldı̆̆ ikincil kitap pazarları için bir elektronik pazar modeli önerilmektedir. Bu modelde katılımcılar kitap alış ve satış isteklerini eşzamanlı olarak elektronik pazar sistemine iletebilirler. Satışa çıkarılan her kitap tekil bir ürün olarak kabul edilir ve fiyatı satıcısı tarafından belirlenir. Önerilen model katılımcıların sisteme ilettikleri istekleri için bütçe sınırı koymalarına da izin verir. Böylece her bir katılımcı için katılımcının satın aldığı kitapların maliyeti ile sattığı kitaplardan elde ettiği gelir arasındaki fark bildirilen bütçe sınırı dahilinde kalır. Bu model ayrıca katılımcıların kendi tercihleri doğrultusunda birbirini ikame edebilir olarak gördükleri kitapları bir liste halinde belirtebilmelerini ve bu listeden en fazla bir adet kitap almalarını sağlayacak bir mekanizmaya da sahiptir. İlave olarak kullanıcılar dilerlerse istedikleri kitapları kişisel tercihlerine göre önceliklendirebilirler. Bu çalışmada, elektronik pazar modelinin matematiksel tanımı yapılmış ve ilgili kazanan belirleme problemi doğrusal tam sayı programı olarak formüle edilmiştir. Bu problem NP-Zor sınıfına ait olduğu için iki tane tek çözüm üzerinde çalışan yapıcı ve bir tane de popülasyon tabanlı Karınca Kolonisi Optimizasyonu yöntemi olmak üzere üç farklı sezgisel yöntem önerilmiş ve bu yöntemlerin performansları kapsamlı bir test paketi üzerinde ölçülmüş̧ür. Sonuçlar, önerilen modelin yüksek sayıda katılımcıyı barındıran büyük ölçekli elektronik pazarlarda verimli bir şekilde kullanılabileceğini göstermektedir.
\end{abstract}

Anahtar Kelimeler: Elektronik Pazar, Pazar Tasarımı, İkinci El Eşya Ticareti, Tam Sayı Programlama, Sezgisel Yöntemler, Karınca Kolonisi Optimizasyonu.

\begin{abstract}
In this study, an electronic market model is proposed for the secondary book markets where used and new books are traded. In this model, participants can submit their book purchase and sales requests to the electronic market simultaneously. Each book that is put on sale is considered as a unique product and its price is determined by the seller. The proposed model also allows participants to set a budget limit for their requests. Thus, for each participant, the difference between the cost of the books purchased by the participant and the revenue obtained from the books sold is within the declared budget limit. This model also has a mechanism that allows participants to specify a list of books that they consider to be substitutable so that they can purchase at most one book from this list. In addition, users can prioritize books according to their personal preferences. In this study, mathematical definition of the model is given, and the related winning determination problem is formulated as linear integer program. Since this problem is NP-Hard, two constructive heuristics and a population-based Ant Colony Optimization heuristic are proposed, and their performances are evaluated on a comprehensive test package. The results show that the proposed model can be used efficiently in large-scale electronic markets with large number of participants.

Keywords: Electronic Market, Market Design, Used Good Trading, Integer Programming, Heuristic Methods, Ant Colony Optimization.

\section{GİRIŞ}

Bilgi teknolojisindeki son gelişmeler, katılımcıların belirli bir yerde, belirli bir zamanda buluşmasını gerektiren geleneksel fiziksel pazarlardan, bu sınırlamaların ortadan kalktığı elektronik pazarlara geçişe imkân sağlamıştır. Elektronik pazarlar, zaman ve mekân kısıtlamalarını zayıflatarak birden fazla alııı ve satıcıyı bir araya getiren bir platform sağlar [1]. Bu nedenle, bir elektronik pazar, fiziksel bir pazardan daha fazla katılımcı çekme potansiyeline sahiptir. Örneğin, dünyanın en büyük çevrimiçi pazarı olan eBay, dünya çapında 180 milyondan fazla müş̧eriye sahiptir [2] ve yine dünyanın en büyük Firmadan-Firmaya (B2B) pazarı olan Alibaba.com'da 670 milyondan fazla aktif katılımcı bulunmaktadır [3]. Bir pazarda katılımcı sayısının artması, tedarikçiler arasında daha yüksek rekabet
\end{abstract}


seviyesi oluşturarak tedarikçi yenilikçiliğinin artmasına neden olmaktadır [4]. Ayrica elektronik pazarlar satıcıların ürün teklifleri hakkında bilgi edinmek için alıcıların arama maliyetlerini de düşürebilir $[5,6] . \mathrm{Bu}$ da pazarın kaynak tahsis verimliliğini arttırır [7].

$\mathrm{Bu}$ çalışma gerek yeni gerekse de kullanılmış kitap ticaretinin yapıldığ İkincil kitap pazarları, milyarlarca dolarlık işlem hacmi ile küresel ekonomik aktivitede önemli bir rol oynamaktadır. Örneğin, ABD'de, kullanılmış kitap pazarının işlem hacmi 2004 yılında yaklaşık 2,2 milyar dolar olarak saptanmıştır ve çevrimiçi kitap satıcıları, genel olarak ikinci el kitap satışlarının üçte ikisinden sorumludur [8]. Ayrıca, fiziksel pazarlara kıyasla, alan gereksinimini azalttığından ötürü elektronik kitap pazarları daha yüksek oranda kitap çeşitliliği sağlamaktadır. Örneğin, Brynjolfsson ve arkadaşlarının çalışmasında [9], amazon.com ve barnesandnoble.com çevrimiçi sitelerinde 2,3 milyon kitap listelenirken, tipik bir fiziksel kitabevinde yalnızca 40.000 ila 100.000 kitap bulunduğu ifade edilmiştir. Benzer şekilde, 21.000 metre karelik bir alanı kaplayan WalMart alışveriş merkezlerinde, Wal-Mart'ın çevrimiçi sitesinde bulunan kitap sayısının en fazla altıda biri bulunduğu belirtilmiştir.

Bu çalışmada, yeni ya da kullanılmış kitapların ticareti için özellikle ikincil kitap pazarları için tasarlanmış, Kitap Elektronik Pazarı (KEP) modeli adı verilen bir elektronik pazar modeli önerilmiştir. $\mathrm{Bu}$ modelde, pazar katılımcıları hem alıcı hem de satıcı rollerine sahip olabilir. Bu da eş zamanlı olarak her katılımcının sahip olduğu kitaplar için satış teklifi verebileceği ve sahip olmak istediği kitaplar için de satın alma taleplerini bildirebileceği anlamına gelir. Satış teklifi verilen her kitap tekil bir ürün olarak kabul edilir ve fiyatı satıcısı tarafından teklif içerisinde belirtilir. $\mathrm{Bu}$ iki yönlü pazar modeli, pazar katılımcıların, satın almak istedikleri kitaplar için satmak istedikleri kitaplardan elde edecekleri geliri harcayabilmelerine imkân verir. Model ayrıca, her kullanıcı için bir bütçe sınırı mekanizması da içermektedir. Öyle ki bu mekanizma ile her katılımcının satın aldığı kitapların toplam tutarı ile sattığ kitaplardan elde edilen gelirin farkı, o katılımcının bildirdiği bütçe sınırını aşamaz. Bu nedenle, bu model bütçesi sınırlı olan katılımcıların, satılacak kitaplarından elde ettikleri gelirleri kullanarak yeni kitaplar satın almalarını sağlar ve bütçe açığı riski olmadan bu kullanıcıların pazara katılmalarını teşvik eder.

Pazarda bir katılımcının satın almak istediği kitabın birden fazla kopyası olabilir ya da katılımcı birden fazla farklı kitap arasından bir tanesini almak istiyor olabilir. Örneğin, katılımcının ilgilendiği bir fizik kitabının pazarda farklı basımları ya da aynı basımın farklı kullanıcılar tarafindan satılan kopyaları olabilir. $\mathrm{Bu}$ katılımc1, bu kitaplar arasından yalnız birini almak isteyebilir. $\mathrm{Bu}$ gibi durumlar için KEP modeli kullanıcıların ikame kitapları belirtebilmelerine imkân veren bir mekanizmaya da sahiptir. Her kullanıcı ikame edilebilir kitapların bir listesini oluşturup, bu liste içerisinden en fazla bir (ya da kaç kitap almak istiyorsa o sayıda) kitap almak istediğini belirtebilir. İlaveten, bu listedeki kitaplar için dilerse öncelik tercihini de belirtebilir. Bu özellikler sayesinde, KEP modeli ikinci el kitap pazarlarına daha fazla katılımcı çekmeyi ve bu pazarların tahsis verimliliğini arttırmayı amaçlamaktadır.

Bir sonraki bölümde, KEP modeli örnek bir kitap pazarı senaryosu üzerinden ayrıntılı olarak açıklanmaktadır. Bölüm 3'te, KEP modelinin matematiksel tanımı verilmiş ve modele ait kazanan belirleme problemi doğrusal tam sayılı programlama kullanılarak formüle edilmiştir. Karmaşıklık analizleri de sunulmuştur. Kazanan belirleme problemi NP-Zor sınıfina dahil olduğundan Bölüm 4'te tek çözüm üzerinde hızlı çalışan iki yapıcı sezgisel yöntem ve ayrıca diğer yöntemlere göre çözüm uzayında daha çok arama yapan popülasyon tabanlı Karınca Kolonisi Optimizasyonu yöntemi önerilmiştir. Bu yöntemlerin kapsamlı bir test paketi üzerindeki performanslarını gösteren deneysel sonuçlar Bölüm 5'te sunulmuştur. Makale Bölüm 6'da sonuçlandırılmıştır.

\section{KITAP ELEKTRONIK PAZAR MODELI}

$\mathrm{Bu}$ çalışmada önerilen KEP modelinde, her katılımcı eşzamanlı olarak kitap alış ve satış isteklerini belirtebilir, dolayısıyla her katılımcı satıcı rolünde, alıcı rolünde veya her iki rolde birlikte olabilir. Modelde katılımcıların istekleri üş aşamada alınır. Birinci aşamada, satıcı rolü olan katılımcılar, satmak istedikleri kitapları sisteme bildirirler. $\mathrm{Bu}$ bildirimlere satış istekleri adı verilir. $\mathrm{Bu}$ modelde, satılacak her kitap tekil bir ürün olarak kabul edilir ve fiyatı sahibi tarafından belirlenir. $\mathrm{Bu}$ özellik, alıcıların farklı satıcılar tarafindan satılan aynı kitabın kopyaları arasında ayrım yapabilmelerini sağlar. Örneğin, kitabın fiyat1, kitabın durumu, satıcısının itibarı, satıcının konumu ve ilgili transfer maliyeti aynı kitabın kopyaları için değişiklik gösterebilir.

İkinci aşamada, alıcı rolü olan katılımcılar, satın almak istedikleri kitapları bildirirler. $\mathrm{Bu}$ bildirimlere alış istekleri adı verilir. Yukarıda da belirtildiği üzere, pazarda aynı kitabın birçok kopyası olabilir veya bir katılımcı, birkaç farklı kitabı eşdeğer olarak değerlendiriyor ve bu kitaplardan sadece birisini almak istiyor olabilir (örneğin birkaç farklı roman arasından bir roman). Bu durum göz önüne alındığında, KEP modelinde katılımcılar alış istekleri içerisinde sadece tek bir kitap değil, bir kitap listesi (istek listesi) bildirmesine izin verilir. Bir katılımc tarafindan oluşturulan her istek listesi, katılımcının bu listedeki bütün kitaplarla ilgilendiğini, ancak bu listedeki kitaplardan yalnızca birini satın almak istediğini belirtir. Ayrıca, katılımcı ilan ettiği istek listesindeki 
kitapları tamamen eşdeğer olarak değerlendirmiyorsa, istek listesi katılımcının öncelik tercihlerini gösterecek şekilde sıralı olarak da verilebilir. Örneğin, bir katılımcının istek listesi \{A Kitabı, C Kitabı, B Kitabı\} şeklinde ise, katılımcının A kitabını, C kitabına, C kitabını da B kitabına tercih ettiği anlaşılır. Modelde her istek listesinden en fazla bir adet kitap alınacağ varsayılmıştır. Ancak bu varsayım aynı listeden daha fazla kitap almak isteyen katılımcılar için bir sınırlama getirmez. Katılımc bir istek listesinden birden fazla kitap almak istiyorsa, o istek listesini başka alış isteği olarak almak istediği kitap sayısı kadar tekrarlar. Alış isteklerinin bu modelde tekil olması gerekli değildir.

Alış ve satış istekleri toplandıktan sonra, üçüncü aşamada alıcı rolü olan her katılımcı isterse bir bütçe sınırı bildirir. Bütçe sınırı, katılımcının pazarda harcamak istediği azami para miktarını gösterir. Katılımcının ayrıca bir satıcı rolü varsa, bütçe sınırı, katılımcının harcama tutarı ile geliri arasındaki azami farkı gösterir. Başka bir deyişle, her katılımcının kitaplara harcadığ 1 tutar ile sattığı kitaplardan elde ettiği gelir arasındaki fark o katılımcının belirlemiş olduğu bütçe sınırını aşamaz.

Pazar sürecinin anlaşılmasını kolaylaştırmak için, Şekil 1 'de gösterilen örnek bir senaryo hazırlanmıştır. Bu senaryoda, dört katılımcı altı farklı kitabı 15 TL ile 40
TL arasında değişen fiyatlarla satışa çıkarmıştır. Örneğin, birinci katılımc1, sahip olduğu A ve B kitaplarını sırasıyla 30 TL ve 20 TL'ye satmak istediğini belirttiği bir satış isteği iletmiştir. Satış isteğine ilave olarak, C ve D kitaplarından da bir tanesini almak istediğini belirten bir alış isteğini de bildirmiştir. $\mathrm{Bu}$ alış isteği ile birinci katılımcı, C kitabını, D kitabına tercih ettiğini de ifade etmektedir. Son olarak katılımcı 10 TL'lik bir bütçe sınırı beyan etmiştir. Görüldüğü üzere, bu bütçe sınırı, katılımcının $C$ veya $D$ kitaplarından herhangi birisini alabilmesi için yeterli değildir. Bu katılımcının bu kitaplardan birisini alabilmesi için satmak istediği kitaplardan en az birinin satılması gerekmektedir.

Benzer şekilde, ikinci katılımcı, sahip olduğu C ve D kitaplarını satmak istediğini belirtmiştir. Fakat birinci katılımcıdan farklı olarak, bu katılımcı iki satın alma isteği bildirmiştir. Hem A kitabını hem de E, F ve B kitaplarından bir tanesini, dolayısıyla toplam iki adet kitap almak istediğini ifade etmiştir. Ayrıca, E kitabını, F kitabına, F kitabını da B kitabına tercih ettiğini de belirtmiştir. Bütçe sınırı olarak 0 TL belirtmesi, katılımcının belirttiği iki kitap alım isteğinin ancak her iki kitabı satılırsa yerine getirilebileceğini göstermektedir.

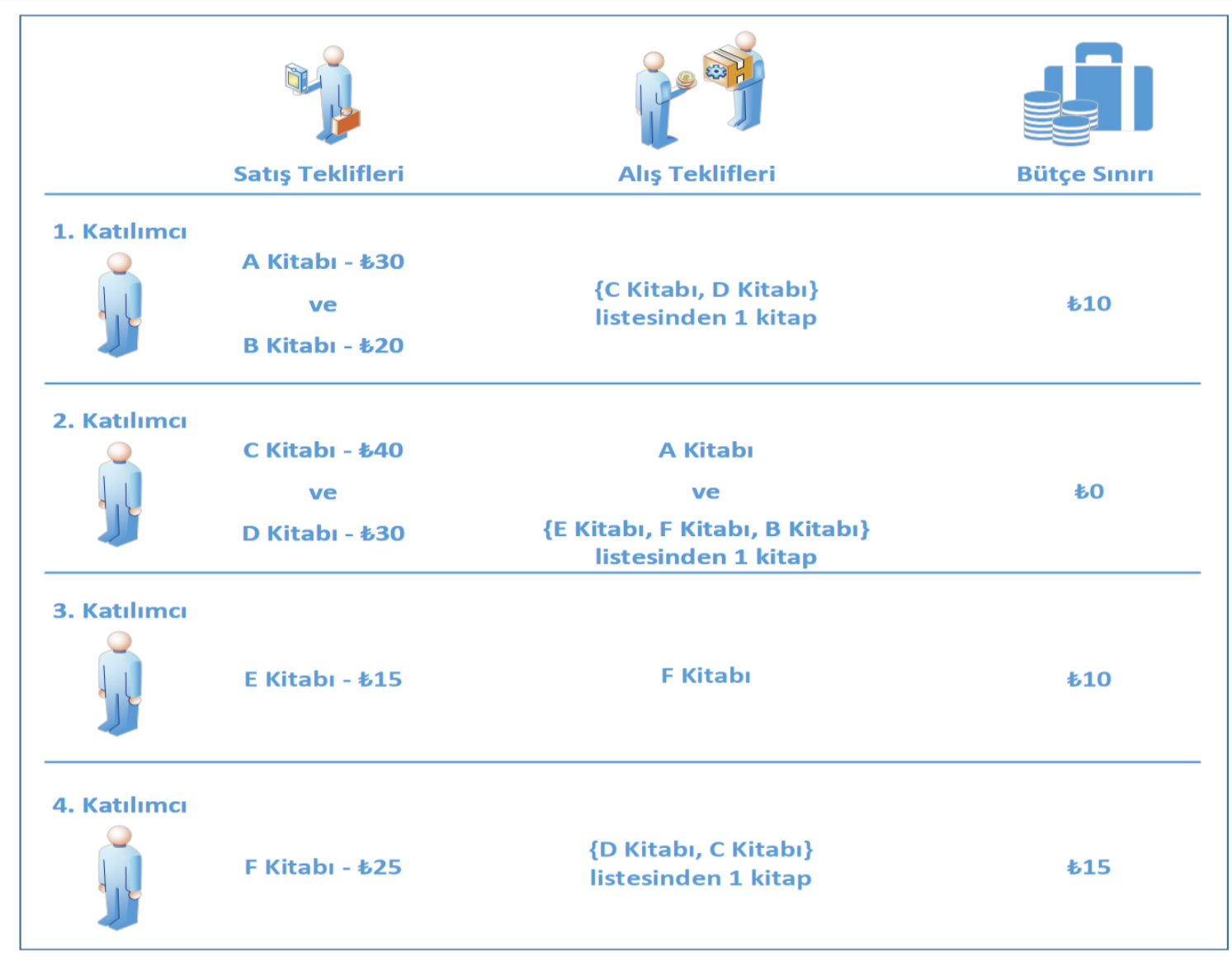

Şekil 1. KEP modeline ait örnek senaryo. 
KEP modelinin temel amacı, katılımcıların kitap satın almak için sattıkları kitaplardan elde edilecek geliri kullanmalarını sağlayarak kitap pazarının tahsis verimliliğini arttırmaktır. $\mathrm{Bu}$ özelliğin yararı bu senaryoda da görülebilir. Katılımcıların bütçe sınırları, istedikleri kitapları satın almalarına izin vermemektedir. Bu nedenle, bu modelin kullanılmadığı geleneksel kitap pazarlarında, önce kitaplarını satışa çıkaracaklar, eğer kitapları satılırsa elde edilen bütçeyi kullanarak yeni kitaplar satın alabileceklerdir. Bu örnek senaryoda, hiçbir katılımcının bütçesi almak istediği herhangi bir kitabı karşılayacak değerde olmadığı için, geleneksel bir pazarda hiçbir katılımcı kitap alıp, satamayacaktı. Bununla birlikte, KEP modelinin kullanıldı ̆̆ 1 bir pazarda bu senaryonun sonucu aşağıdaki gibidir:

- Birinci katılımcı, A kitabını satar ve C kitabını satın alır. Toplam 10 TL harcar ve alışveriş sonundaki bakiyesi 0 TL olur.

- İkinci katılımcı, C ve D kitaplarını satar ve A ve E kitaplarını satın alır. Toplam 25 TL kazanır ve alışveriş sonundaki bakiyesi $25 \mathrm{TL}$ olur.

- Üçüncü katılımcı, E kitabını satar ve F kitabını satın alır. Toplam 10 TL harcar ve alışveriş sonundaki bakiyesi 0 TL olur.

- Dördüncü katılımcı, F kitabını satar ve D kitabını satın alır. Toplam 5 TL harcar ve alışveriş sonundaki bakiyesi $10 \mathrm{TL}$ olur.

- Toplam ticaret hacmi 140 TL olur.

Örnek senaryonun sonucundan görüldüğü gibi, bu model, ticaret tamamlandıktan sonra hiçbir katılımcının bütçesinin açık vermesine, diğer bir deyişle negatif bakiyeye düşmesine izin vermez.

Modelin uygulanması da oldukça basittir. Önceden belirlenmiş bir süre içerisinde katılımcılardan alış ve satış istekleri ile bütçe sınırı değerleri toplanır. Bu sürenin sonunda, bir sonraki bölümde açıklanan eniyileme (optimizasyon) problemi çözülerek pazar dengesi bulunur. Bir katılımcının gerçekleştirilemeyen istekleri, katılımcının isteği doğrultusunda bir sonraki tura aktarılabilir. Her bir turun süresi, katılımcı sayısına ve verilen istek sayısına göre belirlenebilir. Daha uzun süreler, daha iyi tahsis verimliliği sağlar ancak aynı zamanda birim zamanda daha az işlem hacmi oluşmasına neden olur, yani pazar verimini düşürür.

Elektronik pazarlarda genel olarak müzayede veya sabit fiyat mekanizması kullanılır. Örneğin, eBay her iki mekanizmayı da desteklemektedir ve satıcılar kendi uygun gördükleri mekanizmayı tercih edebilmektedirler. Yapılan çok sayıda çalışma (kaynak taraması için bakınız [10]), müzayede mekanizması kullanıldığı durumda satıcıların beklenen gelirinin, sabit fiyat mekanizması kullanıldığı duruma göre daha yüksek olacağını göstermektedir. Bunula birlikte, Einav ve arkadaşları [11] yaptıkları çalışmada, 2016 yılı verilerine göre eBay'de yer alan satıcıların \%90'ından fazlasının sabit fiyat mekanizmasını tercih ettiğini ortaya koymuştur. Bu nedenle KEP modelinde sabit fiyat mekanizması kullanılmıştır. Yazar önceki çalışmasında [12] ise, çift taraflı müzayede tabanlı, DABC adı verilen bir model önermiştir. DABC modelinde KEP modeline benzer olarak bir bütçe sınırlama mekanizmasına sahiptir. Ancak fiyat belirleme mekanizması KEP modelinden oldukça farklıdır. DABC modelinde her satıcı sisteme bir ya da daha fazla satış teklifi iletir. Satış teklifleri satılacak malın tanımını ve satıcının o malı satmak istediği en düşük fiyatı içerir. Alıcılar ise sisteme alış tekliflerini iletirler. Alış teklifleri alınması istenen malı ve alıcının o malı satın almak istediği en yüksek fiyatı içerir. Her bir mal için satış teklifi fiyatı ile alış teklifi fiyatı arasındaki fark fayda değerini belirler. Bir mal için alışveriş fiyatı, k-DA politikası ile belirlenir. DABC modelinin amacı toplam faydayı eniyilemektir. KEP modeli ise kitap elektronik pazarları için önerilmiştir ve sabit fiyat mekanizmasını kullanır. Satılan kitapların fiyatı satıcılar tarafından belirlenir ve alışveriş bu fiyat üzerinden gerçekleştirilir. Alıcılar, DABC modelinin aksine alış teklifleri yerine satın almak istedikleri bir ya da daha fazla kitabı içeren alış isteklerini bildirirler. Alış istekleri fiyat bilgisi içermez ve alış isteklerinde kitapların alıcıların tercihlerine göre önceliklendirilmesi mümkündür. KEP modelinin amacı ise kullanıcıların alış isteklerinde bildirdikleri kitap tercihlerine göre belirlenmiş ağırlık değerlerini baz alarak toplam ticaret hacmini eniyilemektir. Dolayısıyla iki modelin kazanan belirleme problemleri birbirinden farklıdır.

\section{KEP MODELININ MATEMATIKSEL TANIMI VE KAZANAN BELIRLEME PROBLEMI}

KEP modeli matematiksel olarak şöyle tanımlanabilir: $T=\left\{t_{1}, t_{2}, \ldots, t_{m}\right\}$ pazardaki $\mathrm{m}$ adet katılımcının kümesi ve $B_{i}$ de katılımcı $t_{i}$ tarafından satışa çıkarılan kitapların kümesi olsun $(1 \leq i \leq m)$. KEP modelinde her bir kitap tekil olarak tanımlanır. Dolayısıyla pazarda mevcut olan kitaplar kümesi $B=$ $\left\{b_{1}, b_{2}, \ldots, b_{n}\right\}$ ise şu şekilde tanımlanır: $B=$ $\bigcup_{i=1}^{m} B_{i}\left(\forall i, i^{\prime} \mid B_{i} \cap B_{i}^{\prime}=\emptyset\right) . P=\left(p_{b_{1}}, p_{b_{2}}, \ldots, p_{b_{n}}\right)$ listesi kitapların fiyatlarını içerir ki $p_{b_{j}}$ değeri, $b_{j}$ kitabının sahibi tarafından belirlenen fiyatını gösterir $\left(1 \leq j \leq n, \quad p_{b_{j}} \in \mathbb{R}^{+} \cup\{0\}\right)$. Katılımcıların bütçe sinırları ise $L=\left(l_{1}, l_{2}, \ldots, l_{m}\right)$ listesi ile gösterilir ki $l_{i}$ değeri $t_{i}$ katılımcısının bütçe sınırını ifade eder $\left(l_{i} \in\right.$ $\left.\mathbb{R}^{+} \cup\{0\}\right)$.

KEP modelinde bir alış isteği $r_{k}=\left(r_{k 1}, r_{k 2}, \ldots, r_{k z}\right), \mathrm{z}$ adet kitabı içeren ve sahibinin tercihlerine göre yüksek tercih önceliğinden düşüğe doğru sıralanmış olan bir listedir $\left(1 \leq l \leq z, r_{k l} \in B\right)$. Bu da matematiksel olarak, $\left(r_{k 1}>r_{k 2}>\cdots>r_{k z}\right)$ olarak ifade edilir ki $r_{k x}>r_{k y}$ ise alış isteğini veren katılımcı $r_{k x}$ kitabını $r_{k y}$ kitabına tercih ediyor anlamina gelir. Bir $t_{i}$ katılımcısı tarafından bildirilen alış isteklerinin kümesi 
$R_{i}$ ile gösterilir ve and bütün alış istekleri kümesi $R=$ $\left\{r_{1}, r_{2}, \ldots, r_{v}\right\}$ ise $R=\bigcup_{i=1}^{m} R_{i}$ şeklinde tanımlanır.

Bir alış isteğinin anlamı şu şekilde açıklanır: $t_{i}$ katılımcısı $r_{k}$ alış isteğini bildirmekle, $r_{k}$ listesindeki kitaplardan en fazla bir adet almak istediğini ifade etmiş olur. Eğer $r_{k}$ alış isteği içerisinde henüz bir kitap alınmamışsa, ayrıca isteğin içerisinde başkası tarafından satın alınmamıs en az bir kitap varsa ve bu kitabın fiyatı $t_{i}$ katılımcısının bütçesi dahilinde ise $r_{k}$ alış isteği karşılanabilir olarak tanımlanır. Ayrıca $t_{i}$ katılımcısının bütçesi, ya da diğer bir deyişle bakiyesi, satılan kitaplardan elde ettiği gelir + bütçe sınırı değeri - satın aldığı kitapların tutarı şeklinde tanımlanır.

KEP modeline ait Kazanan Belirleme Problemi (KBP) ise birlikte karşılanabilir alış isteklerini içeren olası bütün kümelerin arasından karşılanan isteklere ait ağırlıklı toplamlarının en büyük olanının bulunması problemi olarak tanımlanır. KBP bir birleşimsel optimizasyon problemidir.

KBP, doğrusal tam sayı programlama metodu ile formüle edilebilir. $\mathrm{Bu}$ amaçla, bir ikili değişken $x_{k l}$ tanımlanmıştır. Bu değişken şu şekilde tanımlanır:

$x_{k l}= \begin{cases}1 & \text { eğer alış isteği } r_{k} \text { karşılanarak } r_{k l} \text { kitabı alındı ise } \\ 0 & \text { aksi taktirde }\end{cases}$

KBP, doğrusal tam sayı programlama metodu ile şu şekilde formüle edilebilir:

$$
\begin{gathered}
\max \sum_{\substack{r_{k} \in R \\
r_{k l} \in R_{k}}} w_{k l} \cdot x_{k l} \\
\text { s.t. } \sum_{\substack{r_{k} \in R \\
r_{k l} \in R_{k} \\
r_{k l}=b_{j}}} x_{k l} \leq 1 \quad\left(b_{j} \in B\right) \\
\sum_{\sum_{r_{k} \in R_{i}}} p_{r_{k l} \in R_{k}} x_{r_{k l} \in R_{k}} \leq 1 \quad\left(r_{k} \in R\right) \\
x_{k l}-\sum_{\substack{r_{k} \in R \\
r_{k l} \in R_{k} \\
r_{k l} \in B_{i}}} p_{r_{k l}} x_{k l} \leq l_{i} \quad\left(t_{i} \in T\right) \\
x_{k l} \in\{0,1\}(\forall k, l)
\end{gathered}
$$

Ağırlık değerleri $w_{k l}$ ise şu şekilde tanımlanabilir ( $\alpha$ değeri çözücü tarafından numerik olarak ihmal edilemeyecek kadar büyük ve en küçük para biriminden küçük olacak şekilde seçilen herhangi bir değerdir): $w_{k l}$
$= \begin{cases}p_{r_{k l}} & \text { ĕger } l=0 \text { ise veya } w_{k(l-1)}>p_{r_{k l}} \text { ise } \\ w_{k(l-1)}-\alpha & \text { aksi taktirde }\end{cases}$

$\mathrm{Bu}$ formülasyonda, Eşitlik (2) alınan/satılan kitapların $w_{k l}$ ağırlık değerlerine göre ağırlıklı toplamlarını enbüyütecek şekilde formüle edilmiş amaç fonksiyonudur. $\mathrm{Bu}$ amaç fonksiyonu toplam ticaret hacimini arttırırken kullanıcıların almak istedikleri kitaplar üzerindeki tercihlerini de dikkate alacak şekilde tasarlanmıştır. Eğer sadece ticaret hacmi dikkate alınacak olsaydı $w_{k l}$ ağırlık değerleri ilgili kitabın satış fiyatı olarak belirlenmesi gerekirdi. Bu durumda ise şöyle bir sorun ortaya çıkacaktı: Bir katılımcı alış isteğinde fiyatı farklı iki kitap, örneğin A ve B kitaplarını istemiş olsun. A kitabının fiyatı 10 TL, B kitabının ise 20 TL olduğunu ve katılımcının bu kitaplardan ucuz olanını (A kitabı) pahalı olanına (B kitabı) tercih ettiğini varsayalım. Dolayısıyla katılımcının belirttiği alış isteği \{A Kitabı, B Kitabı\} şeklinde olacaktır. Eğer katılımcının bütçesi bu iki kitabı da almaya izin veriyorsa ve amaç fonksiyonu da ticaret hacmini arttıracak şekilde kullanılmış olursa, A kitabının ağırlık değeri 10, B kitabının ağırlık değeri ise 20 olacaktır. Dolayısıyla bu durumda bu katılımcıya ikinci tercihi olan B kitabı verilecektir ve katılımcının tercihi dikkate alınmamış olacaktır. Ancak Eşitlik (7)'de yer alan ağırlıklandırma metodu ile A kitabının ağırlık değeri yine 10 olacaktır fakat B kitabının ağırlık değeri 9.999 ( $\alpha=0,001$ için) olacaktır. Bu durumda KBP eniyilemisinin sonucunda katılımcı kişisel tercihi ile doğru orantılı olarak A kitabı verilecektir.

Kısıtlar ile ilgili olarak, Eşitlik (3) her kitabın en fazla bir katılıme tarafından satın alınabilmesini sağlar. Eşitlik (4) ise her alış isteği için, istek sahibi tarafından alınabilecek kitap adedini bir ile sınırlar. Son olarak, Eşitlik (5) bütçe kısıtıdır; her katılımcı için satın alınan kitapların toplam maliyeti ile satılan kitapların geliri arasındaki fark, o katılımcının belirtmiş olduğu bütçe sınırını aşmamalıdır.

Alt küme toplamı problemi [13], polinom zamanında KBP'ye indirgenebilir ${ }^{1}$ ve dolayssıyla KBP NP-Zor sınıfina dahildir. Ayrıca tüm katılımcıların bütçe sınırları 0 olduğu durumda, kazanan belirleme problemi ilaveten yaklaşılamaz bir problem haline gelir. Matematiksel ifade ile $\mathrm{P}=\mathrm{NP}$ olmadığ varsayılırsa, KBP için $\varepsilon \in[0,1)$ için polinom zamanlı $\varepsilon$-yaklaşık algoritma olamaz [14]. Ancak, bu negatif sonucun geçerliliği, en az bir katılımcının istediği kitaplardan en az birini satın almak için yeterli bütçeye sahip olması durumunda ortadan kalkacaktır. Ayrıca diğer taraftan, tüm katılımcıların bütçe sınırları, satılan kitaplardan elde edilen geliri kullanmadan istedikleri her kitabı satın almalarına izin verecek kadar çok ise, kazanan belirleme problemi bir ağ akışı problemine

\footnotetext{
${ }^{1}$ Yazarın önceki çalışmasında [12] benzer bir problem için önerdiği indirgeme prosedürü uygun değişikliklerle bu probleme de uygulanabilir.
} 
dönüşür ve böylece polinom zamanda çözülebilir.

\section{SEZGISEL YÖNTEMLER}

KBP, NP-Zor sınıfına ait bir problem olduğu için optimal çözümlerin polinom zamanda bulunabilmesi $\mathrm{P}=\mathrm{NP}$ olmadığı sürece mümkün değildir. Bu sebepten ötürü bu problem için bu makalede üç farklı sezgisel yöntem önerilmektedir. $\mathrm{Bu}$ yöntemlerin ilk ikisi sıfırdan tek bir sonuç oluşturan yapıcı sezgisel yöntem, üçüncüsü ise arama uzayında daha verimli arama yapabilmek amaciyla önerilen popülasyon tabanlı meta-sezgisel bir yöntem olan Karınca Kolonisi Optimizasyonu yöntemidir.

Sıralı Karşılama (SK) olarak adlandırılan ilk sezgisel yönteme ait sözde kod Şekil 2'de görülebilir. Bu yöntemde, ilk olarak girdi olarak verilen KEP modelinin içerisindeki tüm alt istekleri içeren bir $\mathrm{S}$ listesi oluşturulur. Örneğin, bir katılımcının isteği $\{$ Kitap $C$, Kitap A\} ise Kitap $C$ ve Kitap A için ayrı ayrı iki alt istek listeye eklenir. Bir alt istek, Eşitlik (7)'da tanımlanan ağırlık değerini, alt isteğin sahibini, satın alınması istenen kitabı, S listesi içindeki indeksini ve alt isteğin karşılanıp karşılanmadığı belirten bir bayrağ1 içeren bir veri yapısıdır. S listesi oluşturulduktan sonra, listedeki tüm alt istekler karşılanmamış olarak işaretlenir ve liste alt isteklerin ağırlık değerlerine göre azalan şekilde sıralanır.

S listesi sıralandıktan sonra, S listesindeki ilk alt istek geçerli alt istek olarak seçilir ve karşılanıp karşılanamayacağı kontrol edilir. Bir alt istek, aşağıdaki şartların tamamının sağlandığı durumda karşılanabilir olarak tanımlanır:

(i) Alt istek henüz karşılanmamış ise;

(ii) alt isteğin sahibinin, alt istekte istenen kitabı satın almak için yeterli bütçesi varsa;

(iii) aynı isteğin içerisinde başka bir alt istek daha önce karşılanmadıysa;

(iv) alt istekte istenen kitap daha önce satilmadiysa.

$\mathrm{Bu}$ tanıma göre, geçerli alt istek karşılanabilir ise direk olarak karşılanır (Bu tanıma göre bir alt isteğin karşılanabilir olup olmadığını kontrol eden Karşılanabilir() yöntemi tanımlanmıştır). Bir alt istek karşılandığı zaman kitabın ücreti kitabı satın alan katılımcının bakiyesinden düşürülür ve kitabı satan katılımcının bakiyesine eklenir. Ayrıca, alt istekte istenen kitap satıldı olarak işaretlenir ve o alt isteğin içerisinde yer aldığ karşılanamaz hale gelir. Bundan sonra, kitabın sahibine ait karşılanabilir alt isteklerin en küçük indeks değerine sahip olanı bulunur ve geçerli alt isteğin indeksi ile karşılaştırılır. Eğer ilki daha küçük ise, yöntem bu alt isteğe atlar, diğer bir deyişle kitabın sahibine ait karşılanabilir alt isteklerin en küçük indeks değerine sahip olanı geçerli alt istek olarak belirlenir. Eğer halihazırdaki geçerli alt isteğin indeksi daha küçük ise veya geçerli alt istek karşılanamaz bir alt istek ise, $\mathrm{S}$ listesindeki bir sonraki alt isteğe geçilir ve bu alt istek yeni geçerli alt istek olarak işaretlenir. Yöntem, S listesindeki bütün alt isteklerin işlenmesi tamamlandığında sonra sona erer.

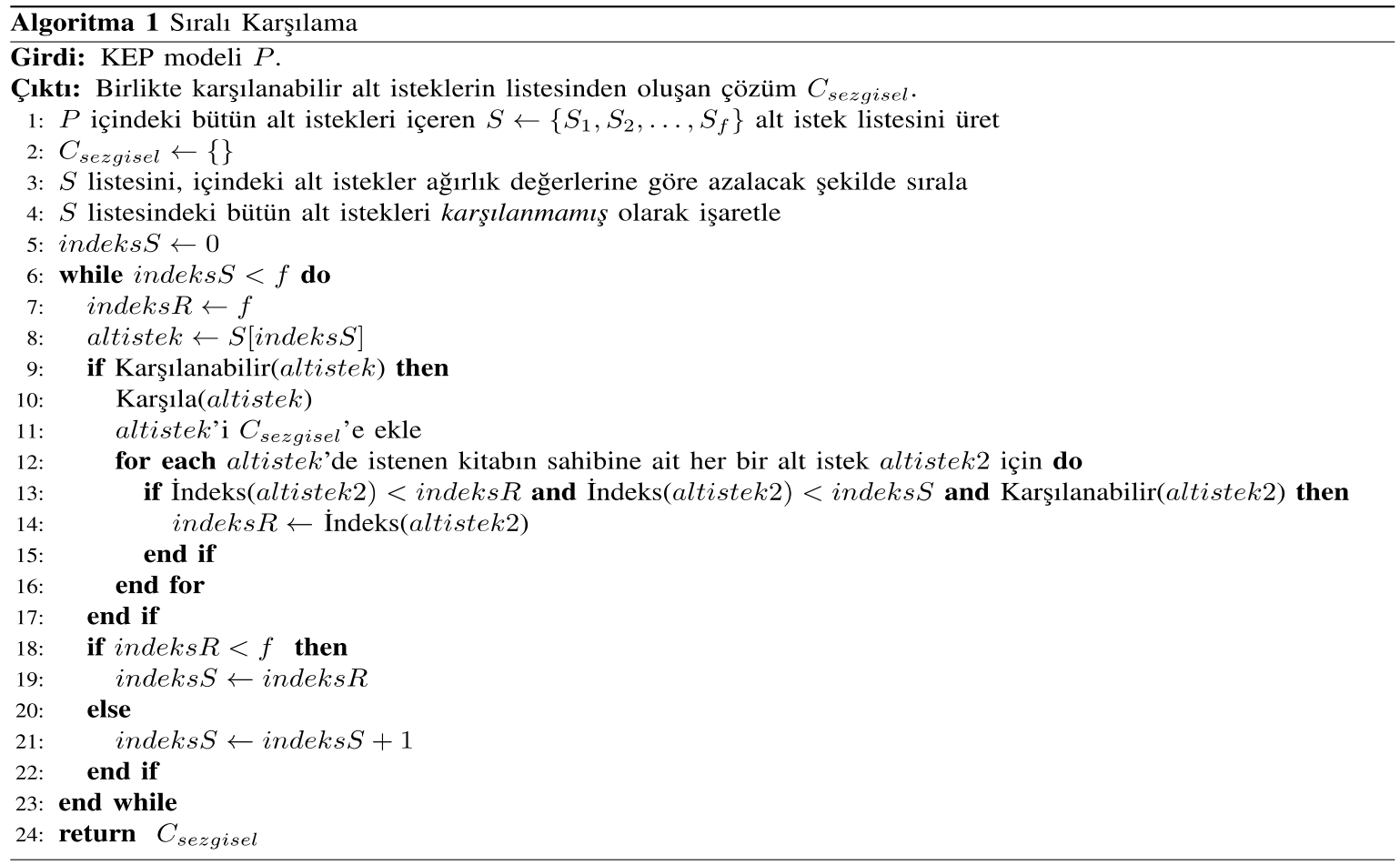

Şekil 2. Sıralı Karşılama Sezgisel Yönteminin Sözde Kodu. 
SK yönteminde, geçerli alt isteğin sahibi, istenen kitabı satın almak için yeterli bütçeye sahipse geçerli alt istek karşılanmaktadır. Önerilen ikinci yöntem olan Gelir Sağlayarak Sıralı Karşılama (GSSK) yönteminde ise eğer alt isteğin sahibi o alt istekte istenen kitabı satın almak için yeterli bütçeye sahip değilse, bir sonraki alt isteğe geçmek yerine, önce alt istek sahibinin gelirinin arttırılmasına çalışılır. GSSK yönteminin sözde kodu Şekil 3'te görülebilir.

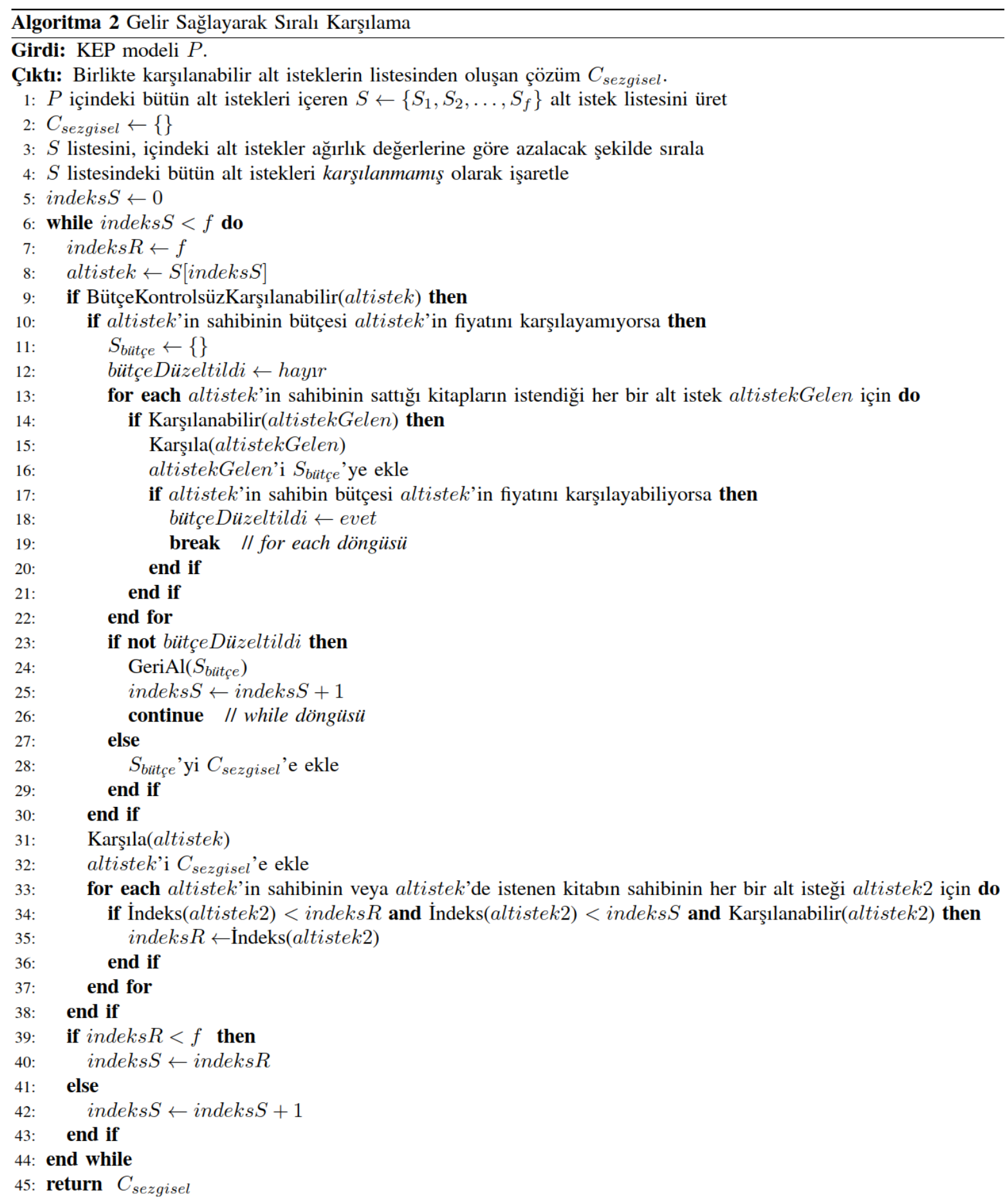

Şekil 3. Gelir Sağlayarak Sıralı Karşılama Sezgisel Yönteminin Sözde Kodu.

Bütçe artışını sağlayabilmek için SK yönteminde kullanılan karşılanabilirlik tanımına göre tanımlanmış Karşılanabilir() yöntemi yerine, GSSK yönteminde bütçe kontrolünü devre dişı bırakan Bütçe Kontrolsüz Karşılanabilir() yöntemi kullanılmıştır. Dolayısıyla, Bütçe Kontrolsüz Karşılanabilir() yöntemi yukarıda listelenen karşılanabilirlik koşullardan (i), (iii), ve (iv) koşullarını kontrol eder. Daha sonra, geçerli alt isteğin sahibi, talep etmiş olduğu kitabı satın almak için yeterli bütçeye sahip değilse, GSSK yöntemi, önce alt istek sahibinin sahip olduğu kitapları isteyen alt istekleri, ki bunlar gelen alt istekler olarak adlandırılır, karşılamaya 
çalışarak, geçerli alt istek sahibinin bütçesini o alt isteği karşılayacak şekilde iyileştirmeye çalışır. Eğer geçerli alt isteğin sahibinin bütçesi yeterli duruma gelebilirse, geçerli alt istek karşılanır. Aksi taktirde, bütçe iyileştirme amacıyla karşılanan gelen alt isteklerin hepsi karşılanmamış durumuna geri alınır. Eğer geçerli alt istek karşılandıysa GSSK yöntemi, bütçesi arttırılan katılımcıların karşılanabilir en küçük indeksli alt isteğinin indeks değerini geçerli alt isteğin indeks değeri ile karşılaştırır, eğer ilki küçükse o alt istek bir sonraki geçerli alt istek olarak belirlenir. Eğer ikincisi küçükse ya da geçerli alt istek karşılanamamışsa, $\mathrm{S}$ listesindeki bir sonraki alt isteğe geçilir ve bu alt istek yeni geçerli alt istek olarak işaretlenir. Yöntem, S listesindeki bütün alt isteklerin işlenmesi tamamlandığında sonra sona erer.

Önerilen SK ve GSSK yöntemleri tek bir çözüm oluşturmak üzere tasarlanmış yapıcı sezgisel yöntemlerdir. Bu çalışmada üçüncü bir sezgisel yöntem olarak popülasyon tabanlı yapıcı bir sezgisel yöntem olan Karınca Kolonisi Optimizasyonu (KKO) yöntemi önerilmiştir. KKO sezgisel yöntemi ilk olarak Dorigo ve arkadaşları tarafından 1990'lı yıllarda önerilmiştir $[15,16]$. Bu yöntemde genel olarak karınca kolonilerine ait gözlemlerden esinlenmiştir.

Karıncalar koloniler halinde yaşayan ve bireysel olarak değil de bir koloni olarak hayatını sürdürmek üzere davranış sergileyen, sosyal yaşam gösteren böceklerdir. KKO yöntemlerinde esas olarak karıncaların yemek arama yönteminden, özel olarak da buldukları yemek kaynağı ile yuvaları arasındaki en kısa mesafeyi bulma yönteminden esinlenilmiştir. Karıncalar yemek ararken, önce yuvalarının etrafını rastgele bir şekilde ararlar. $\mathrm{Bu}$ aramayı yaparken yere iz feromonu ad 1 verilen kokan bir madde birakırlar. Karıncalar feromon kokusunu da alabilir. Yuvasından çıkan bir karınca yemek kaynağına ulaşmak için olasılıksal olarak feromon yoğunluğu yüksek olan yolu takip eder [17].

KKO yöntemi ilk olarak Dorigo ve arkadaşları [15] tarafından Karınca Sistemi adı altında gezgin satıcı problemine uygulanmıştır. Daha sonra yöntem çeşitli şekillerde geliştirilmiştir. $\mathrm{Bu}$ geliştirmelerden en bilinenlerinden bir tanesi Dorigo ve Gambardella [18] tarafindan önerilen Karınca Kolonisi Sistemi yöntemidir. Karınca Kolonisi Sistemi, Karınca Sistemine nazaran daha verimli çalışmakta ve daha büyük boyutlu problemleri çözebilmektedir. KKO yöntemleri ile ilgili daha kapsamlı bir tartışma Doriga ve Stützle'nin kitabında bulunabilir [19].

$\mathrm{Bu}$ çalışmada KBP için büyük boyutlu problemleri çözebilecek şekilde verimli olduğu için Karınca Kolonisi Sistemi tabanlı KKO yöntemi uygulanmıştır $[18,20]$. Bu yönteme ait sözde kod Şekil 4'te görülebilir. Bu yöntemde ilk olarak başlangıç feromon değeri, $\gamma$, hesaplanmaktadır. $\mathrm{Bu}$ değer, verilen problemin önce GSSK yöntemi kullanılarak bulanan toplam ağırlık değerinin ölçeklenmesi ile bulunur. KKO yönteminde verilen problemde yer alan her bir alt istek için bir feromon değeri içeren, $\vec{p}$ feromon vektörü kullanılır. Bu vektördeki tüm değerler hesaplanmış olan başlangıç feromon değerine, $\gamma$, eşitlenir.

Feromon vektörü hazırlandıktan sonra verilen problem için seçkinci seçme yöntemi kullanılarak popülasyon büyüklüğü, diğer bir deyişle karınca sayısı kadar yeni çözümler üretilir. Oluşturulan popülasyon içindeki çözümlerin en iyisi (en yüksek toplam ağırlığa sahip olanı), şimdiye kadar bulunan en iyi çözümle karşılaştırılır ve gerekirse bulunan en iyi çözüm güncellenir. Daha sonra feromon buharlaşma oranı, $\beta$, parametresine bağlı olarak feromon değerleri, başlangıç feromon değerine, $\gamma$, yaklaşacak şekilde azaltılır. $\mathrm{Bu}$ işleme feromon buharlaşması adı verilmektedir. Daha sonra, şimdiye kadar bulunan en iyi sonuç içerisinde karşılanmış olan her bir alt isteğe ait feromon değeri, feromon seçkinci güncelleme oranı, $\alpha$, parametresine bağlı olarak arttırılır. Arttırma oranı şimdiye kadar bulunan en iyi sonucun toplam ağırlık değeriyle doğru orantılıdır. $\mathrm{Bu}$ işleme feromon güncellemesi adı verilmektedir. Feromon güncellenmesi tamamlandiktan sonra yeni bir popülasyon oluşturulması işlemi ile devam edilir. Bulunan en iyi sonuç $t$ parametresi ile belirlenen sayıda popülasyon üretildikten sonra bile hala değişmemişse, yöntem sonlandırılır. 


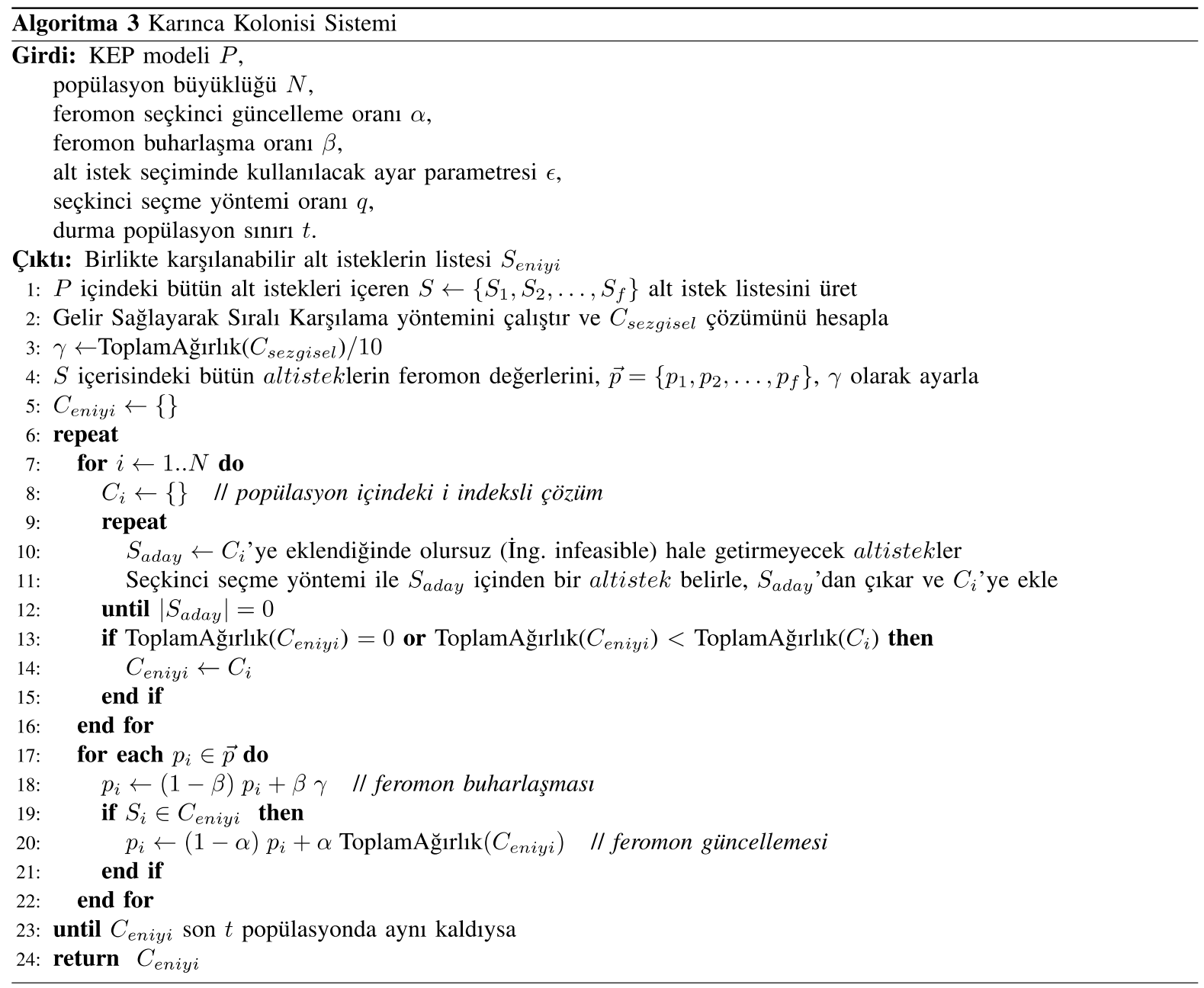

Şekil 4. Karınca Kolonisi Sistemi Yönteminin Sözde Kodu.

$\mathrm{Bu}$ yöntemde, bir popülasyon içindeki çözümler oluşturulurken yukarıda da belirtildiği üzere seçkinci seçme yöntemi [20] kullanılır. Seçkinci seçme yönteminde öncelikli olarak her bir alt isteğin, $S_{i}$, cazibe değeri aşağıdaki formüle göre hesaplanır:

$$
\text { Cazibe }\left(S_{i}\right)=p_{i} \times \operatorname{Ağ} ı r l ı k\left(S_{i}\right)^{\epsilon}
$$

Bu formülde, $p_{i}, S_{i}$ alt isteğine ait feromon değerini, $\operatorname{Ağ} \iota r l ı k\left(S_{i}\right), S_{i}$ alt isteğinin ağırlık değerini gösterir. Alt istek seçiminde kullanılacak ayar parametresi, $\epsilon$, ise yöntemin ayarlanabilir bir girdi parametresidir. Bir alt isteğin ağırlığının feromon değerine nazaran cazibesine olan etkisini belirler.

Daha sonra sıfırdan karşılanabilir alt istekler birer birer karşılanarak çözüm oluşturulur. Karşılanacak olan alt isteğin seçiminde, seçkinci seçme oranı, $q$, parametresi $(0 \leq q \leq 1)$ kullanılır. Sürekli düzgün dağılıma uygun olarak 0 ile 1 arasında rastgele bir sayı üretilir. Bu sayı $q$ değerinden küçük ise karşılanabilir alt istekler içerisinden cazibe değeri en yüksek olan alt istek seçilir. Eğer değilse o zaman turnuva seçimi yöntemi ile rastgele bir karşılanabilir alt istek seçilir. Seçilen alt istek karşılanarak çözüme eklenir. Karşılanabilir bir alt istek kalmayana kadar bu işleme devam edilir.
Dolayısıyla bu yöntemde oluşturulan çözümlere ilave edilebilecek karşılanabilir bir alt istek kalmayacağ garanti edilir. Diğer bir deyişle oluşturulan bütün çözümler olurlu bölgenin sınırındadır.

\section{DENEYSEL SONUÇLAR VE TARTISMA}

Önerilen sezgisel yöntemlerin gerçek hayattaki pazar koşullarında gösterecekleri performansları tahmin edebilmek üzere bir test problemi üreteci geliștirilmiş ve bir test paketi hazırlanmıştır. Test problemi üreteci, tüm yaygın sürekli ve kesikli rasgele sayı dağılımlarını destekleyen sözde rastgele sayllar üretmek için GNU Scientific Library [21] kullanır. Oluşturulan test paketi, farklı pazar koşullarını test edebilmek üzere 1280 farklı problemden oluşmaktadır. $\mathrm{Bu}$ problemlerde satışa sunulan kitap ve satın alma istek sayıları Poisson dağılımıyla ortalama değeri 600 ile 1500 arasında, her bir istek içerisinde istenen kitap sayısı ise yine Poisson dağılımıyla ortalama değeri 2 ile 5 arasında değişecek şekilde belirlenmiştir. İlaveten ortalama boyutu 10 ile 100 kitap arasında değişen boyutta kitap öbekleri tanımlanmış ve satın alma isteklerinde istenen kitaplar bu öbeklerdeki kitaplar arasından düzgün dağılımla belirlenmiştir. Test problemlerindeki kitapların fiyatları ise Ghose ve arkadaşlarının [22] Amazon.com 
kitap pazarındaki satış bilgilerinden oluşturdukları istatistiksel profil kullanılarak belirlenmiştir.

Bölüm 3 'te belirtildiği üzere, tüm katılımcıların bütçe sınırı sıfır olduğu zaman, KEP problemi yaklaşılmaz bir problem olur ve dolayısıyla optimal değil, olurlu bir çözüm bulmak dahi zor bir problem haline gelir. Esasen bu problemlerin muhtemelen toplam ağırlık değerinin (amaç değeri) sıfirdan büyük olan olası bir çözümü yoktur. Öte yandan, tüm katılımcılar tüm olası satın alımları için yeterli bütçeye sahip olduklarında, problem oldukça kolay hale gelmekte, polinom zamanda optimal sonuç bulunabilmektedir. Aslında, gerçek hayat pazarlarında karşılaşılacak olan problemler çoğunlukla bu iki nokta arasında olacaktır. $\mathrm{Bu}$ nedenle, test paketi kapsamında oluşturulan problemlerde katılımcıların bütçe sınırlarını belirlemek için \%10 ile \%80 arasında değişen beş farklı bütçe sınır oranı kullanılmıştır. Bu oran değerleri kullanılarak, $t_{i}$ katılımcısının bütçe sınırı, $l_{i}$, şöyle hesaplanır:

$$
l_{i}=b s o_{i} \times\left(b t c_{i}^{m a k s}-b t c_{i}^{m i n}\right)+b t c_{i}^{\min }
$$

Bu formülde $b s o_{i}, t_{i}$ katılımcısının bütçe sınır oranını, $b t c_{i}^{\text {min }}, t_{i}$ katılımcısının bütün kitaplarının satıldığ varsayıldığında, satın almak istediği en ucuz bir tane kitabı almak için gerek duyacağı en düşük bütçe miktarını, $b t c_{i}^{\text {maks }}$, ise $t_{i}$ katılımcısının hiçbir kitabının satılmadığı varsayıldığında, satın almak istediği bütün kitapları (alternatifler içerisinde en pahalısı seçilerek) alabilmesi için gerekli en düşük bütçe miktarını ifade eder.

Üretilen test problemleri, 128 GB belleğe ve iki adet 8 çekirdekli $3.10 \mathrm{GHz}$ CPU'ya sahip bir sunucuda, 64 bit Linux işletim sistemi üzerinde çalışan Gurobi Karma Tam Sayılı Programlama (KTP) çözücüsünün 8. sürümü [23] kullanılarak çözülmüştür. Çözücü tek bir iş parçacığı kullanacak şekilde yapılandırılmış ve her bir problem için 60 dakikalık bir zaman sınırı tanımlanmıştır. Oluşturulan test paketine optimal çözümlerin makul bir zamanda bulunabilmesi için özellikle büyük ölçekli problemler dahil edilmediği halde (en fazla 1500 istek içeren problemler üretilmiştir) test paketi içerisinde yer alan 1280 problemden belirtilen zaman sınırı dahilinde ancak 1174 tanesinin (\%91,7'sinin) optimal sonucu bulunabilmiştir. Yapılan deneylerde bu sonuçlar kullanılmıştır.

$\mathrm{Bu}$ çalışmada önerilen üç sezgisel yöntemin, SK, GSSK ve KKO, başarımlarını değerlendirmek için hazırlanan test paketi içinde yer alan her bir test problemi bu yöntemlerle çözülmüş ve elde edilen sonuçlar aynı problem için Gurobi KTP çözücüsünün bulduğu sonuçlarla kıyaslanmıştır. Bu kıyaslama için sezgisel yöntemler tarafından oluşturulan çözümlerin kalitesini gösterebilmek amacıyla aşağıdaki şekilde tanımlanan iyilik oranı kullanılmıştır:

$$
\begin{aligned}
& \text { Bir Çözümün İyilik Oranı } \\
& =\frac{\text { Sezgisel Yöntemin Bulduğ } u \text { Ağırlık Değeri }}{\text { Optimal Ă̆ } ı r l ı k \text { Değeri }} \times 100
\end{aligned}
$$

Ancak kıyaslamayı yapmadan önce, sezgisel yöntemlerin parametrelerinin değerlerinin belirlenmesi gerekmektedir. Önerilen SK ve GSSK yöntemlerinde ayarlanabilir bir parametre bulunmamaktadır. Ancak KKO yönteminde Şekil 4'te de görüldüğü üzere 6 farklı parametre mevcuttur. Bu parametrelerin belirlenmesi için Karınca Kolonisi Sisteminin tanıtıldığı ve uygulandığı Dorigo ve Gambardella'nın çalışmasından [18] yararlanılmıştır. Bu doğrultuda alt istek seçiminde kullanılacak ayar parametresinin, $\epsilon$, değeri 2 olarak, durma popülasyon sınırı, $t$, parametresinin değeri ise 50 olarak tanımlanmıştır.

Diğer dört parametreden üçünün uygun değerleri ise yapılan ilk deney ile belirlenmiştir. Bu deneyde feromon seçkinci güncelleme ve buharlaşma oranlarının, $\alpha, \beta$, ve seçkinci seçme yöntemi oranının, $q$, değişik değerleri için test paketindeki problemler KKO yöntemi ile çözülmüştür. $\mathrm{Bu}$ parametrelerin değişimine bağlı olarak KKO yönteminin optimal sonuçlara göre iyilik oranları Tablo 1'de görülebilir. Dikkat edilmelidir ki, bu testlerde Dorigo ve Gambardella'nın çalışmasında [18] kullanıldığı şekliyle feromon seçkinci güncelleme ve buharlaşma oranları aynı değerde olacak şekilde belirlenmiştir. Bu parametrelerin birbirleriyle etkileşimini ve parametrelerin değişimlerine bağlı olarak ortalama iyilik oranları arasındaki farkların istatistiksel olarak anlamlı olup olmadığını saptamak için iki yönlü ANOVA testi (iki yönlü varyans analizi) uygulanmıştır. Test sonuçlarına göre, \%99 güven aralığında feromon seçkinci güncelleme ve buharlaşma oranları, $\alpha, \beta$, ve seçkinci seçme yöntemi oranı, $q$, arasında iyilik oranı için istatiksel olarak anlamlı bir etkileşim bulunmamaktadır $(\mathrm{F}(4,31716)=3,117, \mathrm{p}=$ 0,014, kısmi $\eta 2<0,0005)$. Dolayısıyla, ana etkiler incelenebilmiştir. Ana etkilerin sonuçları şöyledir:

- Farklı feromon seçkinci güncelleme ve buharlaşma oranları, $\alpha, \beta$, için ortalama iyilik oranında \%99 güven aralığında istatistiksel olarak anlamlı bir fark bulunmamaktadır $(\mathrm{F}(2$, 31716) $=0,382, \mathrm{p}=0,683$, k1smi $\eta 2<0,001)$.

- Farklı seçkinci seçme yöntemi oranları, $q$, için ortalama iyilik oranları arasındaki fark \%99 güven aralığında istatistiksel olarak anlamlıdır $(\mathrm{F}(2,31716)=69,486, \mathrm{p}<0,0005, \mathrm{k} 1 \mathrm{smi} \eta 2=$ 0,004). Dolayısıyla çoklu karşılaştırma yapılmıştır.

- $\quad$ Seçkinci seçme yöntemi oranı, $q=0,9$ için elde edilen ortalama iyilik oranı değeri, seçkinci seçme yöntemi oranı, $q=0,7$ için elde edilen ortalama iyilik oranı değerinden $\% 0,7$ daha yüksektir ve bu fark \%99 güven aralığında istatistiksel olarak anlamlıdır ( $\mathrm{p}<$ 0,0005, aralık: \%0.4 - \%1.1). 
- $\quad$ Seçkinci seçme yöntemi oranı, $q=0,7$ için elde edilen ortalama iyilik oranı değeri, seçkinci seçme yöntemi oranı, $q=0,5$ için elde edilen ortalama iyilik oranı değerinden $\% 0,6$ daha yüksektir ve bu fark \%99 güven aralığında istatistiksel olarak anlamlıdır ( $\mathrm{p}<$ 0,0005, aralık: \%0.2 - \%0.8).
- $\quad$ Seçkinci seçme yöntemi oranı, $q=0,9$ için elde edilen ortalama iyilik oranı değeri, seçkinci seçme yöntemi oranı, $q=0,5$ için elde edilen ortalama iyilik oranı değerinden \%1.3 daha yüksektir ve bu fark \%99 güven aralığında istatistiksel olarak anlamlıdır $(\mathrm{p}<$ 0,0005, aralık: \%0.9 - \%1.6).

Tablo 1. Feromon seçkinci güncelleme ve buharlaşma oranlarının $(\alpha, \beta)$ ve seçkinci seçme yöntemi oranının $(q)$ değişimlerine göre karınca kolonisi optimizasyonu yönteminin optimal sonuçlara göre iyilik oranları (Ort:

Ortalama, SS: Standart Sapma). Yapılan testlerde güncelleme ve buharlaşma oranları aynı değerde kullanılmıştır.

\begin{tabular}{|c|c|c|c|c|c|c|c|c|}
\hline \multirow{3}{*}{$\begin{array}{c}\text { Feromon Seçkinci Güncelleme ve } \\
\text { Buharlaşma Oranı }(\alpha, \beta)\end{array}$} & \multicolumn{8}{|c|}{ Seçkinci Seçme Yöntemi Oranı (q) } \\
\hline & \multicolumn{2}{|c|}{0,5} & \multicolumn{2}{|c|}{0,7} & \multicolumn{2}{|c|}{0,9} & \multicolumn{2}{|c|}{ Genel } \\
\hline & Ort & SS & Ort & SS & Ort & SS & Ort & SS \\
\hline 0,1 & $\% 90,5$ & $\% 8,0$ & $\% 90,5$ & $\% 7,7$ & $\% 91,6$ & $\% 7,6$ & $\% 90,9$ & $\% 7,8$ \\
\hline 0,3 & $\% 90,3$ & $\% 8,1$ & $\% 91,1$ & $\% 7,7$ & $\% 91,6$ & $\% 7,7$ & $\% 91,0$ & $\% 7,9$ \\
\hline 0,5 & $\% 90,2$ & $\% 8,1$ & $\% 91,0$ & $\% 7,8$ & $\% 91,6$ & $\% 7,7$ & $\% 91,0$ & $\% 7,9$ \\
\hline $\bar{~} \overline{\text { Genel }}$ & $\overline{7 \% 90,3}$ & $\overline{~ \% 8,1}$ & \%\%90,9 & $\overline{~ \% 7,8}$ & \%91,6 & $\% 77,7$ & \%90,9 & $\overline{~ \% 7,9}$ \\
\hline
\end{tabular}

Ayrıca yine bu parametrelerin değişimine bağlı olarak KKO yönteminin çalışma zamanları da Tablo 2'de verilmiştir. Parametrelerin değişimine bağlı olarak, çalışma zamanlarının ortalama değerlerindeki farkların istatistiksel olarak anlamlı olup olmadığını saptamak için yine iki yönlü ANOVA testi (iki yönlü varyans analizi) uygulanmıştır. Test sonuçlarına göre, feromon seçkinci güncelleme ve buharlaşma oranları, $\alpha, \beta$, ve seçkinci seçme yöntemi oranı, $q$, arasında iyilik oranı arasında $\% 99$ güven aralığında istatiksel olarak anlamlı bir etkileşim bulunduğu görülmektedir $(\mathrm{F}(3,31716)=$ $18,795, \mathrm{p}<0,0005$, k1smi $\eta 2=0,002)$. Dolayısıyla ana etkiler yerine, basit ana etkiler incelenmiştir. Basit ana etkilere bağlı olarak yapılan çoklu karşılaştırma sonuçları Tablo 3 ve Tablo 4'te görülebilir.

Tablo 2. Feromon seçkinci güncelleme ve buharlaşma oranlarının $(\alpha, \beta)$ ve seçkinci seçme yöntemi oranının $(q)$ değişimlerine göre karınca kolonisi optimizasyonu yönteminin çalışma süreleri (saniye cinsinden, Ort: Ortalama,

SS: Standart Sapma). Yapılan testlerde güncelleme ve buharlaşma oranları aynı değerde kullanılmıştır.

Seçkinci Seçme Yöntemi Oranı $(q)$

\begin{tabular}{|c|c|c|c|c|c|c|c|c|}
\hline \multirow{3}{*}{$\begin{array}{l}\text { Feromon Seçkinci Güncelleme ve } \\
\text { Buharlaşma Oranı }(\alpha, \beta)\end{array}$} & \\
\hline & \multicolumn{2}{|c|}{0,5} & \multicolumn{2}{|c|}{0,7} & \multicolumn{2}{|c|}{0,9} & \multicolumn{2}{|c|}{ Genel } \\
\hline & Ort & SS & Ort & SS & Ort & SS & Ort & SS \\
\hline 0,1 & 23,2 & 19,9 & 22,5 & 21,2 & 22,1 & 23,3 & 22,6 & 21,5 \\
\hline 0,3 & 23,8 & 21,2 & 21,4 & 19,1 & 19,5 & 20,6 & 21,6 & 19,8 \\
\hline 0,5 & 25,7 & 23,9 & 23,2 & 23,3 & 18,7 & 18,7 & 22,5 & 22,3 \\
\hline Genel & 24,2 & 21,8 & 22,4 & 21,3 & 20,1 & 21,0 & 22,2 & 21,4 \\
\hline
\end{tabular}


Tablo 3. Seçilen bir seçkinci seçme yöntemi oranına (q) göre feromon seçkinci güncelleme ve buharlaşma oranları $(\alpha, \beta)$ parametresinin değişiminin karınca kolonisi optimizasyonu yöntemine ait ortalama çalışma süresine olan etkisinin iki-yönlü ANOVA testi ve çoklu karşılaştırma yöntemi ile analizi. Her bir basit ana etki içerisindeki çoklu karşılaştırmalar için Bonferroni düzeltmesi uygulanmıştır. (*) işaretli değerler ilgili ortalama çalışma süreleri arasındaki farkın \%99 güven aralığında istatistiksel olarak anlamlı olduğunu göstermektedir.

\begin{tabular}{|c|c|c|c|}
\hline $\begin{array}{l}\text { Seçilen Seçkinci } \\
\text { Seçme Yöntemi } \\
\text { Oranı }(q)\end{array}$ & $\begin{array}{c}\text { Birinci Karşılaştırılan } \\
\text { Feromon Seçkinci } \\
\text { Güncelleme ve Buharlaşma } \\
\text { Oranı }(\alpha, \beta)\end{array}$ & $\begin{array}{c}\text { İkinci Karşılaştırılan } \\
\text { Feromon Seçkinci } \\
\text { Güncelleme ve Buharlaşma } \\
\text { Oranı }(\alpha, \beta)\end{array}$ & $\begin{array}{c}\text { Ortalama Çalışma } \\
\text { Süreleri Arasındaki } \\
\text { Fark (saniye) }\end{array}$ \\
\hline \multirow{6}{*}{0,5} & \multirow{2}{*}{0,1} & 0,3 & -0.605 \\
\hline & & 0,5 & $-2.546 *$ \\
\hline & \multirow{2}{*}{0,3} & 0,1 & 0.605 \\
\hline & & 0,5 & $-1.942 *$ \\
\hline & \multirow{2}{*}{0,5} & 0,1 & $2.546 *$ \\
\hline & & 0,3 & $1.942 *$ \\
\hline \multirow{6}{*}{0,7} & \multirow{2}{*}{0,1} & 0,3 & 1.092 \\
\hline & & 0,5 & -0.745 \\
\hline & \multirow{2}{*}{0,3} & 0,1 & -1.092 \\
\hline & & 0,5 & $-1.837 *$ \\
\hline & \multirow{2}{*}{0,5} & 0,1 & 0.745 \\
\hline & & 0,3 & $1.837 *$ \\
\hline \multirow{6}{*}{0,9} & \multirow{2}{*}{0,1} & 0,3 & $2.566 *$ \\
\hline & & 0,5 & $3.45 *$ \\
\hline & \multirow{2}{*}{0,3} & 0,1 & $-2.566 *$ \\
\hline & & 0,5 & 0.884 \\
\hline & \multirow{2}{*}{0,5} & 0,1 & $-3.45 *$ \\
\hline & & 0,3 & -0.884 \\
\hline
\end{tabular}

Tablo 4. Seçilen bir feromon seçkinci güncelleme ve buharlaşma oranına $(\alpha, \beta)$ göre seçkinci seçme yöntemi oranı (q) parametresinin değişiminin karınca kolonisi optimizasyonu yöntemine ait ortalama çalışma süresine

olan etkisinin iki-yönlü ANOVA testi ve çoklu karşılaştırma yöntemi ile analizi. Her bir basit ana etki içerisindeki çoklu karşılaştırmalar için Bonferroni düzeltmesi uygulanmıştır. (*) işaretli değerler ilgili ortalama çalışma süreleri arasındaki farkın \%99 güven aralığında istatistiksel olarak anlamlı olduğunu göstermektedir.

\begin{tabular}{|c|c|c|c|}
\hline $\begin{array}{l}\text { Seçilen Feromon Seçkinci } \\
\text { Güncelleme ve } \\
\text { Buharlaşma Oranı }(\alpha, \beta)\end{array}$ & $\begin{array}{c}\text { Birinci Karşılaştırılan Seçkinci } \\
\text { Seçme Yöntemi Oranı }(q)\end{array}$ & $\begin{array}{c}\text { İkinci Karşılaştırılan } \\
\text { Seçkinci Seçme } \\
\text { Yöntemi Oranı }(q)\end{array}$ & $\begin{array}{c}\text { Ortalama Çalışma } \\
\text { Süreleri Arasındaki } \\
\text { Fark (saniye) }\end{array}$ \\
\hline \multirow{6}{*}{0,1} & \multirow{2}{*}{0,5} & 0,7 & 0.693 \\
\hline & & 0,9 & 1.059 \\
\hline & \multirow{2}{*}{0,7} & 0,5 & -0.693 \\
\hline & & 0,9 & 0.366 \\
\hline & \multirow{2}{*}{0,9} & 0,5 & -1.059 \\
\hline & & 0,7 & -0.366 \\
\hline \multirow{6}{*}{0,3} & \multirow{2}{*}{0,5} & 0,7 & $2.390 *$ \\
\hline & & 0,9 & $4.230 *$ \\
\hline & \multirow{2}{*}{0,7} & 0,5 & $-2.390 *$ \\
\hline & & 0,9 & $1.840 *$ \\
\hline & \multirow{2}{*}{0,9} & 0,5 & $-4.230 *$ \\
\hline & & 0,7 & $-1.840 *$ \\
\hline \multirow{6}{*}{0,5} & \multirow{2}{*}{0,5} & 0,7 & $2.494 *$ \\
\hline & & 0,9 & $7.056 *$ \\
\hline & \multirow{2}{*}{0,7} & 0,5 & $-2.494 *$ \\
\hline & & 0,9 & $4.562 *$ \\
\hline & \multirow{2}{*}{0,9} & 0,5 & $-7.056 *$ \\
\hline & & 0,7 & $-4.562 *$ \\
\hline
\end{tabular}


$\mathrm{Bu}$ sonuçlara bakıldığında en iyi ortama değerleri sağlayan Feromon seçkinci güncelleme ve buharlaşma oranları, $\alpha, \beta$, için 0.5 değerinin, seçkinci seçme yöntemi oranı, $q$, içinse 0.9 değerinin uygun olduğu değerlendirilmiş ve bir sonraki deneyde bu değerler kullanılmıştır. Sonuncu parametre olan popülasyon büyüklüğü parametresinin, $\mathrm{N}$, etkisi ise yine bir sonraki deneyde incelenecektir.

KKO yönteminin parametreleri belirlendikten sonra, yapılan ikinci deney kapsamında önerilen üç sezgisel yöntemin başarımlarını ölçmek üzere test paketi içindeki bütün problemler bu yöntemlerle ile çözülmüştür. Elde edilen sonuçlara göre önerilen yöntemlerin iyilik oranlarına ait kutu grafiği ve ortalama iyilik oranları Şekil 5'de görülebilir. Tek çözüm üreten yapıcı sezgisel yöntemler olan SK ve GSSK yöntemleri sırasıyla $\% 83$ ve $\% 87$ ortalama iyilik oranını sağlamışlardır. İki yöntem arasındaki \%4'lük fark, GSSK yönteminde kullanılan gelir arttırma özelliğinin kayda değer fayda sağladığını göstermektedir.

Popülasyon temelli sezgisel yöntem olan KKO yöntemi ise beklenileceği üzere SK ve GSSK yöntemlerine göre ortalamada daha iyi sonuçlar vermektedir. Kullanılan popülasyon büyüklüğüne (karınca sayısı olarak da anılmaktadır), 10, 20 ya da 30, bağlı olarak ortalama başarısı \%91 ile \%92 arasında değişmektedir (yukarıda belirtildiği üzere bu deneylerde $\alpha=\beta$ için 0,$5 ; q$ için 0,9 değeri kullanılmıştır). Ayrıca her bir problem için KKO yönteminin deneylerde kullanılan bütün parametre değerleri için ( $\alpha$ ve $\beta$ için 0,1 veya 0,3 veya 0,$5 ; q$ için 0,5 veya 0,7 veya 0,$9 ; N$ için 10 veya 20 veya 30) bulabildiği en iyi sonuçların ortalama iyilik oranı ise yaklaşık olarak \%93'e yükselmektedir.

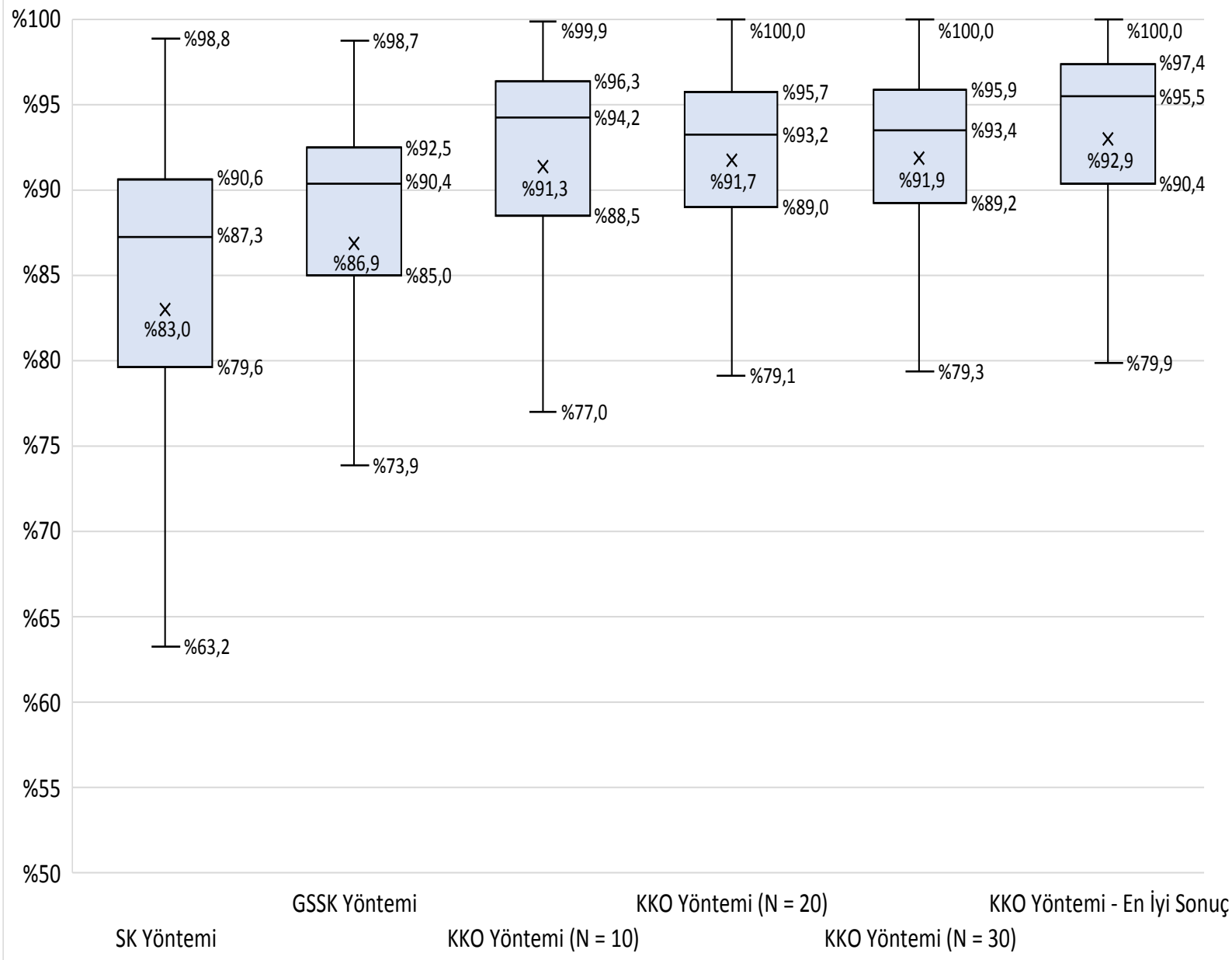

Şekil 5. Önerilen sezgisel yöntemlerin optimal çözümlere göre iyilik oranlarını gösteren kutu grafiği. ' $x$ ' işareti ortalama değeri göstermektedir.

$\mathrm{Bu}$ deneye ait sonuçlardaki ortalama değerler arasındaki farkın istatiksel olarak anlamlı olup olmadığını anlamak için tek yönlü ANOVA testi (tek yönlü varyans analizi) ve akabinde Tukey testi tabanlı çoklu karşılaştırma testi yapılmıştır [24]. Elde edilen sonuçlara göre \%99 güven aralığında GSSK yöntemine ait ortalama iyilik değeri, SK yönteminin ortalama iyilik değerinden, KKO yönteminin kullanılan herhangi bir popülasyon büyüklüğü için (KKO Yöntemi N=10, 20 ve 30) sağladığı ortalama iyilik değerinin ise GSSK 
yönteminin ortalama iyilik değerinden anlamlı olarak farklı olduğu görülmüştür. Ayrıca yine bu seviyede, parametrelerin değerlerinin sabit olduğu diğer KKO yöntemlerinin ortalama iyilik değerlerine göre, KKO yönteminin sağladığı en iyi sonuçlara ait ortalama iyilik değerlerindeki artışın da anlamlı olduğu görülmüştür. Yalnız KKO yönteminde sadece popülasyon büyüklüğünün arttığı (KKO Yöntemi $\mathrm{N}=10,20$ ve 30) durumda, \%95 güven aralığında bile istatiksel olarak anlamlı bir artış görülmemiştir. Dolayısıyla popülasyon büyüklüğünün 10 'dan daha fazla bir değerde kullanılmasının çözüm kalitesinin artışı anlamında ilave bir fayda getirmeyebileceği değerlendirilmektedir.

$\mathrm{Bu}$ bölümde son olarak önerilen sezgisel yöntemlerin çalışma zamanları incelenecektir. Çözülen problemlerdeki istek sayılarına bağlı olarak önerilen sezgisel yöntemlerin ve KTP çözücüsünün çalışma zamanlarına ait istatistiki bilgiler

Tablo 5'te görülebilir.

Tablo 5. Toplam istek sayısının değişimine göre önerilen sezgisel yöntemlerin ve optimal çözüm elde etmek için kullanılan Karma Tam Sayı Programlama (KTP) çözücüsünün saniye cinsiden çalışma zamanları (Ort: Ortalama, SS: Standart Sapma).

\begin{tabular}{|c|c|c|c|c|c|c|c|c|}
\hline \multirow[b]{3}{*}{ Sezgisel Yöntemler } & \multicolumn{8}{|c|}{ Toplam İstek Sayısı } \\
\hline & \multicolumn{2}{|c|}{600} & \multicolumn{2}{|c|}{900} & \multicolumn{2}{|c|}{1200} & \multicolumn{2}{|c|}{1500} \\
\hline & Ort & SS & Ort & SS & Ort & SS & Ort & SS \\
\hline SK Yöntemi & $<0.01$ & $<0.01$ & $<0.01$ & $<0.01$ & $<0.01$ & $<0.01$ & $<0.01$ & $<0.01$ \\
\hline GSSK Yöntemi & $<0.01$ & $<0.01$ & $<0.01$ & $<0.01$ & $<0.01$ & $<0.01$ & $<0.01$ & $<0.01$ \\
\hline KKO Yöntemi (N=10) & 3.7 & 2.2 & 7.2 & 4.4 & 11.8 & 7.7 & 15.5 & 9.5 \\
\hline KKO Yöntemi (N=20) & 7.3 & 4.6 & 14.2 & 8.8 & 23.2 & 15.4 & 31.8 & 20.9 \\
\hline KKO Yöntemi (N=30) & 11.2 & 6.3 & 22.2 & 13.1 & 33.6 & 22.0 & 44.4 & 27.3 \\
\hline KTP Cözücüsü (Optimal Cözüm) & 767 & 2567 & 1149 & 3171 & 1244 & 3328 & 1004 & 2919 \\
\hline
\end{tabular}

SK ve GSSK yöntemleri oldukça hızlı olup, en çok istek sayısına sahip problemler için bile saniyenin yüzde birinden daha kısa bir zamanda sonuç bulabilmektedir. Dolayısıyla bu yöntemlerin çok yüksek sayıda katılımcı içeren elektronik pazarlarda dahi kullanılabileceği değerlendirilmektedir. KKO yöntemi ise popülasyon tabanlı olduğundan diğer iki yönteme nazaran daha yavaş çalışmaktadır ve popülasyon büyüklüğünün 10 olduğu durumda ortalama çalışma süresi yaklaşık 16 saniyeye kadar artabilmektedir. Beklenildiği üzere $\mathrm{KKO}$ yöntemlerinde popülasyon büyüklüğündeki artışın yöntemin çalışma zamanında doğru orantılı bir artışa neden olduğu görülmektedir. Bölüm 3 'te tartışıldığ üzere KBP, NP-Zor sınıfına dahil olduğundan optimal çözümlerin bulunması çok zaman alabilmektedir. Makul sürede çözüm bulunabilmesi amacıyla nispeten küçük ölçekli problemler üretilmiş olduğu halde, bu problemlerin optimal sonuçlarını bulmanın sezgisel yöntemlere nazaran çok daha fazla zaman (problem başına yaklaşık 1000 saniye kadar) almakta olduğu görülmektedir.

\section{SONUC}

14 Nisan 2002 tarihli kullanılmış kitap satışlarıyla ilgili açık mektubunda, Amazon.com CEO'su Jeff Bezos şunları yazdı: “... bir müşteri kullanılmış kitaplar sattığında, bu onlara daha fazla yeni kitap satın alabilmeleri için bir bütçe sağlar." [25]. Bununla birlikte, mevcut kitap pazarlarında, yeni kitap satın alma bütçesi olmayan bir katılımcının, gelir elde etmek için önce kitaplarını satması gerekir. Bu çalışmada, bu sorunun ortadan kaldırmak amaciyla yeni ve kullanışmış kitap satışı için bir elektronik pazar modeli olan KEP modeli önerilmiştir. Bu modelde katılımcılar eşzamanlı olarak kitap alış ve satış isteklerini pazar düzenleyicisine iletebilirler ve satın almak istedikleri kitaplar için satmak istedikleri kitaplardan elde edecekleri geliri harcayabilirler. İlaveten her katılımcı için satın alacağı kitapların maliyeti ile satacağı kitapların geliri arasındaki farkın, katılımcının beyan ettiği bütçe sınırını aşamaması için modelde bir bütçe sınırlama mekanizması da sağlanmıştır. $\mathrm{Bu}$ mekanizma, katılımcılara, kitaplarının satılamayacağ1 durumda bile, potansiyel bir bütçe açığı tehlikesi olmadan alış isteklerini iletebilmeleri olanağını verir. Ayrıca, katılımcıların alternatif olarak gördükleri kitapları belirtebilmelerine izin veren bir mekanizma da mevcuttur. $\mathrm{Bu}$ mekanizmalar sayesinde, KEP modelinin kitap pazarlarındaki katılımcı sayısının ve tahsis verimliliğinin artışını sağlayacağı düşünülmektedir.

$\mathrm{Bu}$ çalışmada, KEP modeli matematiksel olarak tanımlanmış ve KEP modeline ait kazanan belirleme problemi bir doğrusal tam sayı programı olarak formüle 
edilmiştir. Bu problem NP-Zor sınıfina dahil olduğu için, üç adet sezgisel yöntem önerilmiştir. $\mathrm{Bu}$ yöntemlerin başarımlarının ölçülmesi amacıyla kapsamlı bir problem test paketi oluşturulmuş ve önerilen yöntemlerle bu problemler çözülmüştür. Yapılan deneylerde önerilen yöntemlerden ilk ikisinin çok hızlı çalıştığı ve optimal sonuçlara ortalamada \%80'inin üzerinde bir oranda yaklaştığ1, popülasyon tabanlı karınca kolonisi optimizasyonu yönteminin ise optimal çözümü hesaplayan karma tam sayı programlama çözücüsüne nazaran çok daha kısa bir zamanda optimal çözümlere ortalamada yaklaşık \%92'lik bir oranda yaklaştığı görülmüştür. Önerilen yöntemlerin optimal sonucun makul zamanda bulunamayacağı sayıda yüksek sayıda katılımcı içeren elektronik pazarlarda verimli bir şekilde kullanılabileceği değerlendirilmektedir. Son olarak her ne kadar bu çalışma ikincil kitap pazarlarına odaklanmış olsa da modelin diğer dayanıklı tüketim mallarının alışverişinin yapıldığı ikincil pazarlara da uygulanabilir olduğu dikkate alınmalıdır.

\section{TEŞEKKÜR}

Bu çalışma Marmara Üniversitesi Bilimsel Araştırma Projeleri Koordinasyon Birimince desteklenmiştir. Proje Numaras1: FEN-A-130612-0218.

\section{KAYNAKLAR}

[1] Grieger, M., (2003). Electronic marketplaces: A literature review and a call for supply chain management research. European Journal of Operational Research, 144(2), 280-294. doi: 10.1016/S0377-2217(02)00394-6

[2] eBay, (2019). eBay Fast Facts. https://investors.ebayinc.com/fast-facts/default.aspx, (Haziran 2020).

[3] Alibaba Group, (2019). Alibaba Group Announces June Quarter 2019 Results.

https://www.alibabagroup.com/en/news/press_pdf/p19 0815.pdf, (Haziran 2020).

[4] Kambil A., Nunes P.F., \& Wilson D., (1999). Transforming the Marketspace with All-in-One Markets. International Journal of Electronic Commerce, 3(4), 11-28.

doi: 10.1080/10864415.1999.11518346

[5] Bakos J.Y., (1991). A Strategic Analysis of Electronic Marketplaces. MIS Quarterly, 15(3), 295. doi: $10.2307 / 249641$

[6] Bakos J.Y., (1997). Reducing Buyer Search Costs: Implications for Electronic Marketplaces. Management Science, 43(12), 1676-1692.

doi: $10.1287 / \mathrm{mnsc} .43 .12 .1676$

[7] Lee H-G., (1998). Do electronic marketplaces lower the price of goods? Commun. ACM, 41(1), 73-80. doi: $10.1145 / 268092.268122$

[8] Wyatt E., (2005). Internet grows as a factor in used- book business. New York Times.

https://www.nytimes.com/2005/09/29/books/internetgrows-as-factor-in-usedbook-business.html, (Haziran 2020).

[9] Brynjolfsson E., Hu Y., \& Smith M.D., (2003). Consumer Surplus in the Digital Economy: Estimating the Value of Increased Product Variety at Online Booksellers. Management Science, 49(11), 15801596. doi: 10.1287/mnsc.49.11.1580.20580

[10] Bajari P., \& Hortaçsu A., (2004). Economic Insights from Internet Auctions. Journal of Economic Literature, 42(2), 457-486.

doi: 10.1257/0022051041409075

[11] Einav L., Farronato C., Levin J. \& Sundaresan N., (2018). Auctions versus Posted Prices in Online Markets. Journal of Political Economy, 126(1), 178215. doi: $10.1086 / 695529$

[12] Özer A.H., (2019). A double auction based mathematical market model and heuristics for internetbased secondhand durable good markets. Computers \& Operations Research, 111: 116-129.

doi: 10.1016/j.cor.2019.06.005

[13] Garey M.R., \& Johnson D.S., (1979). Computers and intractability. A guide to the theory of NPcompleteness. A series of books in the mathematical sciences. Freeman, San Francisco, California.

[14] Güntzer M.M., Jungnickel D., \& Leclerc M., (1998). Efficient algorithms for the clearing of interbank payments. European Journal of Operational Research, 106(1), 212-219.

doi: 10.1016/S0377-2217(97)00265-8

[15] Dorigo M., Maniezzo V., \& Colorni A., (1996). Ant system: optimization by a colony of cooperating agents. IEEE Transactions on Systems, Man, and Cybernetics, Part B (Cybernetics), 26(1), 29-41.

doi: $10.1109 / 3477.484436$

[16] Dorigo M., Maniezzo V., \& Colorni A., (1999). Positive Feedback as a Search Strategy. Teknik Rapor, 91-016, Dip Elettronica, Politecnico di Milano, Italy.

[17] Blum C., (2005). Ant colony optimization: Introduction and recent trends. Physics of Life Reviews 2(4), 353-373. doi: 10.1016/j.plrev.2005.10.001

[18] Dorigo M., \& Gambardella L.M. (1997). Ant colony system: a cooperative learning approach to the traveling salesman problem. IEEE Trans. Evol. Computat. 1(1), 53-66. doi: 10.1109/4235.585892

[19] Dorigo M., \& Stützle T., (2004). Ant colony optimization. MIT Press, Cambridge, Mass., London.

[20] Luke S., (2013). Essentials of Metaheuristics, second edition, Lulu.

[21] GNU, (2019). GNU Scientific Library. https://www.gnu.org/software/gsl/, (Haziran 2020).

[22] Ghose A., Smith M. D., \& Telang R., (2006). 
Internet Exchanges for Used Books: An Empirical Analysis of Product Cannibalization and Welfare Impact. Information Systems Research, 17(1), 3-19. doi: 10.1287/isre.1050.0072

[23] Gurobi, (2019). Gurobi Optimization. https://www.gurobi.com, (Haziran 2020).

[24] Sokal R.R., \& Rohlf F.J., (1969). Biometry. The principles and practice of statics in biological research. Freeman, San Francisco.

[25] Bezos J., (2002). Open letter on used book sales. https://web.archive.org/web/20161002140853/http://ar chive.oreilly.com/pub/wlg/1291, (Haziran 2020). 